\title{
The CXCR2 Gene Polymorphism Is Associated with Stroke in Patients with Essential Hypertension
}

\author{
Yanina R. Timasheva Timur R. Nasibullin Olga E. Mustafina \\ Institute of Biochemistry and Genetics, USC RAS, Ufa, Russia
}

\section{Key Words}

Ischemic stroke $\cdot$ Chemokines · CXCR2 Essential hypertension

\begin{abstract}
Hypertension is the major risk factor for stroke, and genetic factors contribute to its development. Inflammation has been hypothesized to be the key link between blood pressure elevation and stroke. We performed an analysis of the association between inflammatory mediator gene polymorphisms and the incidence of stroke in patients with essential hypertension (EH). The study group consisted of 625 individuals (296 patients with noncomplicated EH, 71 hypertensive patients with ischemic stroke, and 258 control subjects). Both patients and controls were ethnic Tatars originating from the Republic of Bashkortostan (Russian Federation). The analysis has shown that the risk of ischemic stroke was associated with the CXCR2 rs1126579 polymorphism. Our results indicate that among patients with $\mathrm{EH}$, the heterozygous genotype carriers had a higher risk of stroke $(O R=1.72,95 \% \mathrm{CI} 1.01-2.92)$, whereas the $C X C R 2{ }^{*} \mathrm{C} / \mathrm{C}$ genotype was protective against stroke $(\mathrm{OR}=0.32,95 \% \mathrm{CI} 0.12-0.83)$. As shown by the gene-gene interaction analysis, the CXCR2 rs1126579 polymorphism was also present in all genotype/allele combinations associated with the risk of stroke. Genetic patterns associated with stroke also included polymorphisms in the CCL2, CCL18, CX3CR1, CCR5, and CXCL8 (IL8) genes, although no association between these loci and stroke was detected by individual analysis.
\end{abstract}

(C) 2015 The Author(s)

Published by S. Karger AG, Basel

\section{Introduction}

Arterial hypertension is an established risk factor for stroke, although the exact mechanisms of the development of cerebrovascular complications of hypertension remain unclear. Inflammation plays an important role in cardiovascular system remodeling that leads both to elevated blood pressure and stroke. 
Timasheva et al.: The CXCR2 Gene Polymorphism Is Associated with Stroke in Patients with Essential Hypertension

Chemokines are small proinflammatory mediators that act as chemoattractants and recruit leukocytes to the site of inflammation. Chemokines constitute the largest family of cytokines, consisting of approximately 50 ligands, 20 signaling and 5 nonsignaling receptors [1]. Chemokines act synergistically with common risk factors promoting atherosclerosis development and mediate cell communications during cerebral ischemia.

In the present paper, we studied the association between chemokines and their receptor gene polymorphisms and the risk of stroke in patients with essential hypertension (EH).

\section{Materials and Methods}

The study group consisted of 296 patients with EH without cardiovascular complication (mean age $49.32 \pm 9.37$ years), 71 patients with $\mathrm{EH}$ who suffered from ischemic stroke (mean age $52.55 \pm 6.31$ years), and 258 healthy individuals (mean age $43.41 \pm 7.05$ years) without clinical symptoms of cardiovascular or cerebrovascular disease. Both patients and controls were men of the Tatar ethnic group from the Republic of Bashkortostan (Russia). Patients enrolled in the study were treated at the Republic Centre of Cardiology and the Ufa City Emergency Hospital (Ufa, Republic of Bashkortostan, Russia). Controls were recruited at the Republic Centre of Blood Transfusion (Ufa, Republic of Bashkortostan, Russia). The Clinical characteristics of the study groups are provided in table 1.

DNA was isolated from $8 \mathrm{ml}$ of whole venous blood using standard phenol-chloroform extraction. Genotyping was performed using PCR-RFLP or PCR with the allele-specific primers method with primers designed using PrimerSelect 5.05 software (DNAStar Inc., Madison, Wisc., USA). For the CCL2 rs1024611 ( $-2518 \mathrm{~A}>\mathrm{G})$ polymorphism, the primer sequences were as follows: F 5'-cagcgggggagggcatct- $3^{\prime}$, R 5'-acagggaaggtgaagggtat-3'; restriction enzyme PvuII; fragment lengths: Aallele $105 \mathrm{bp}$, G-allele $51 \mathrm{bp}$, and $54 \mathrm{bp}$. For the CCL18 rs8073066 polymorphism, $\mathrm{F} 5^{\prime}$-tgtgatctgtgctgctcccat- ${ }^{\prime}$ and $\mathrm{R} 5^{\prime}$-cctgcttatcaagccaaaggtc- ${ }^{\prime}$ ' as well as the $B s r I$ restriction enzyme were used; fragment lengths: $\mathrm{C}$-allele 144 and $91 \mathrm{bp}$, and T-allele 235 bp. For the CCR2 rs1799864 [190 A>G (Val64Ile)] polymorphism, the primers were $\mathrm{F} 5^{\prime}$-tgcggtgtttgtgttgtgtggtca-3' and R 5'-agatggccaggttgagcaggt- $3^{\prime}$; restriction endonuclease FokI; fragment lengths: $A(I)$-allele 198, 84, and $74 \mathrm{bp}$, and G(V)-allele 282 and $74 \mathrm{bp}$. For the CX3CR1 rs3732378 [848 A>G (Thr280Met)] polymorphism, the primers were F 5'-ggactgagcgcccacacagg-3' and R 5'-aggctggccctcagtgtgact-3'; restriction enzyme Alw26I; fragment lengths: A-allele $148 \mathrm{bp}$, G-allele 128 and $20 \mathrm{bp}$. For detection of the CCR5 rs333 ( $\triangle 32 \mathrm{I} / \mathrm{D}$ ) polymorphism, we used the following primers: $\mathrm{F} 5^{\prime}$-tgccgcccagtgggactttg- $3^{\prime}$ and $\mathrm{R} 5^{\prime}$-cggcaggaccagccccaag-3'; fragment lengths: I-allele $350 \mathrm{bp}$, D-allele $318 \mathrm{bp}$. The CXCR2, CXCL1, and CXCL8 (IL8) polymorphisms were genotyped using allele-specific primers. For the CXCR2 rs1126579 (+1235 T>C) polymorphism, the primer sequences were: $\mathrm{F} 5^{\prime}$-ggcacacttccactactctcta-3', R 5'-gcagagctccagcaaatga-3', C-allele 5'-cccattgtggtcacaggaag-3', and T-allele $5^{\prime}$-cccattgtggtcacaggaagt- $3^{\prime}$. The positive control fragment length was $253 \mathrm{bp}$, and the amplified allele fragment was $124 \mathrm{bp}$. For the CXCL1 rs4074 (57 A>G) polymorphism, the primer sequences were $\mathrm{F} 5^{\prime}$-gccttcatttgaggcccagt-3', R $5^{\prime}$-aatgggtgccctgagtaggt-3', G-allele $5^{\prime}$-ctggggaaactgcattcggag- $3^{\prime}$, and A-allele $5^{\prime}$-ctggggaaactgcattcggaa- $3^{\prime}$; they produced positive control of $277 \mathrm{bp}$ and allele of $102 \mathrm{bp}$. For the CXCL8 (IL8) rs4073 (-251 A>T) polymorphism, we used the following primers: F $5^{\prime}$-tgattggctggcttatcttca- $3^{\prime}, \mathrm{R} 5^{\prime}$-tcagggcaaacctgagtcatc$3^{\prime}$, A-allele $5^{\prime}$-tccacaatttggtgaattatgaat- $3^{\prime}$, and T-allele $5^{\prime}$-tccacaatttggtgaattatgaaa- $3^{\prime}$. The positive control length was $316 \mathrm{bp}$, and the allele length was $196 \mathrm{bp}$.

Amplification was performed in a T100 ${ }^{\mathrm{TM}}$ thermal cycler (BioRad, Berkeley, Calif., USA) programmed for an initial denaturation step $\left(95^{\circ} \mathrm{C}\right.$ for $\left.1 \mathrm{~min}\right)$ followed by 28 cycles of amplification (denaturation at $95^{\circ} \mathrm{C}$ for $20 \mathrm{~s}$, primer annealing at a specific temperature for $30 \mathrm{~s}$, 


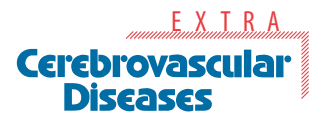

\begin{tabular}{l|l}
\hline Cerebrovasc Dis Extra 2015;5:124-131 \\
\hline DOI: $10.1159 / 000441529$ & $\begin{array}{l}\text { C 2015 The Author(s). Published by S. Karger AG, Basel } \\
\text { www.karger.com/cee }\end{array}$
\end{tabular}

Timasheva et al.: The CXCR2 Gene Polymorphism Is Associated with Stroke in Patients with Essential Hypertension

Table 1. Clinical characteristics of the study groups

\begin{tabular}{|c|c|c|c|}
\hline Parameter & Control & $\mathrm{EH}$ & $\mathrm{EH}+$ stroke \\
\hline Subjects & 258 & 296 & 71 \\
\hline Age, years & $43.41 \pm 7.05$ & $49.32 \pm 9.37$ & $52.55 \pm 6.31$ \\
\hline & male & male & male \\
\hline Age at onset, years & n.a. & $43.16 \pm 8.32$ & $42.19 \pm 8.89$ \\
\hline \multicolumn{4}{|l|}{ Risk factors } \\
\hline \multicolumn{4}{|l|}{ Family history } \\
\hline Hypertension & $20(7.75)$ & $57(19.26)$ & $16(22.54)$ \\
\hline Cerebrovascular disease & $7(2.71)$ & $44(14.86)$ & $14(19.72)$ \\
\hline Hypertension + cerebrovascular disease & $3(1.16)$ & $16(5.41)$ & $3(4.23)$ \\
\hline Hypertension (SBP $\geq 140 \mathrm{~mm} \mathrm{Hg}$ and/or DBP $\geq 90 \mathrm{~mm} \mathrm{Hg}$ ) & $0 \%$ & $100 \%$ & $80 \%$ \\
\hline SBP & $121.97 \pm 4.51$ & $158.66 \pm 15.02$ & $150.00 \pm 11.55$ \\
\hline DBP & $80.20 \pm 2.13$ & $95.13 \pm 8.64$ & $96.25 \pm 2.13$ \\
\hline Smoking & $140(54.26)$ & $184(62.16)$ & $45(63.38)$ \\
\hline Physical inactivity & $166(64.34)$ & $189(63.85)$ & $36(50.7)$ \\
\hline Unhealthy diet & $17(6.59)$ & $42(14.19)$ & $20(28.17)$ \\
\hline Glucose & n.a. & $5.02 \pm 1.94$ & $4.23 \pm 0.68$ \\
\hline Cholesterol & n.a. & $5.16 \pm 1.31$ & $5.40 \pm 1.39$ \\
\hline LDL & n.a. & $3.30 \pm 1.13$ & $3.61 \pm 1.16$ \\
\hline Obesity & $19(7.36)$ & $46(15.54)$ & $20(28.17)$ \\
\hline Overweight & $164(63.57)$ & $195(65.88)$ & $41(57.5)$ \\
\hline BMI & $25.66 \pm 3.48$ & $27.37 \pm 3.75$ & $29.56 \pm 4.97$ \\
\hline
\end{tabular}

Values are shown as means \pm standard deviation or $\mathrm{n}(\%)$, unless otherwise indicated. SBP = Systolic blood pressure; DBP = diastolic blood pressure; $\mathrm{LDL}=$ low-density lipoprotein; $\mathrm{BMI}=$ body mass index; n.a. = not applicable.

elongation at $72^{\circ} \mathrm{C}$ for $30 \mathrm{~s}$ ) and a final extension $\left(72^{\circ} \mathrm{C}\right.$ for $\left.4 \mathrm{~min}\right)$. PCR and restriction products were separated by the electrophoresis on $2 \%$ agarose gel and identified using MegaBioprint 1100 gel documentation system (Vilber Lourmat, Collégien, France).

The study data were stored and managed using IBM SPSS Statistics for Windows, version 22.0. For each SNP, compliance with Hardy-Weinberg expectations was tested using Arlequin 3.0 software. Fisher's two-tailed exact test was applied to estimate the differences between allele and genotype frequency distribution in the study groups. The association between allele and/or genotype combinations and the risk of stroke was analyzed by APSampler 3.6.0; the program and its description are available at https://code.google.com/p/apsampler (common algorithm has been described elsewhere [2]). To adjust for multiple testing, we used the standard permutation test.

\section{Statement of Ethics}

The study protocol was approved by the Ethics Committee of the Institute of Biochemistry and Genetics, USC RAS, Ufa, Russia, and written informed consent was obtained from each participant.

\section{Results}

The observed genotype and allele frequency distribution of the studied loci are shown in table 2. Genotype frequencies for all SNPs were in accordance with the Hardy-Weinberg equilibrium. Distribution of the CXCR2 rs1126579 genotype frequencies differed significantly 
Timasheva et al.: The CXCR2 Gene Polymorphism Is Associated with Stroke in Patients with Essential Hypertension

Table 2. Genotype and allele frequency distribution in the study groups

\begin{tabular}{|c|c|c|c|c|c|}
\hline Genotype/allele & $\begin{array}{l}\text { Control } \\
\mathrm{p} \pm \mathrm{s}_{\mathrm{p}} \\
\text { (CI) }\end{array}$ & $\begin{array}{l}\mathrm{EH} \\
\mathrm{p} \pm \mathrm{s}_{\mathrm{p}} \\
(\mathrm{CI})\end{array}$ & $\begin{array}{l}\text { Stroke } \\
\mathrm{p} \pm \mathrm{s}_{\mathrm{p}} \\
(\mathrm{CI})\end{array}$ & $\begin{array}{l}\mathrm{EH} \\
\mathrm{p} \\
\mathrm{OR}\left(\mathrm{CI}_{\mathrm{OR}}\right)\end{array}$ & $\begin{array}{l}\text { Stroke } \\
\mathrm{p} \\
\mathrm{OR}\left(\mathrm{CI}_{\mathrm{OR}}\right)\end{array}$ \\
\hline \multicolumn{6}{|l|}{ CXCL1 } \\
\hline $\mathrm{G} / \mathrm{G}$ & $\begin{array}{l}26.47 \pm 2.52 \\
(21.61-31.79)\end{array}$ & $\begin{array}{l}34.85 \pm 3.07 \\
(28.85-41.24)\end{array}$ & $\begin{array}{l}26.76 \pm 5.25 \\
(16.94-38.59)\end{array}$ & $\begin{array}{l}\mathbf{0 . 0 3 9} \\
1.49(1.03-2.15)\end{array}$ & 1.000 \\
\hline $\mathrm{A} / \mathrm{G}$ & $\begin{array}{l}53.92 \pm 2.85 \\
(48.16-59.61)\end{array}$ & $\begin{array}{l}46.47 \pm 3.21 \\
(40.05-52.99)\end{array}$ & $\begin{array}{l}56.34 \pm 5.89 \\
(44.05-68.09)\end{array}$ & 0.086 & 0.792 \\
\hline $\mathrm{A} / \mathrm{A}$ & $\begin{array}{l}19.61 \pm 2.27 \\
(15.31-24.51)\end{array}$ & $\begin{array}{l}18.67 \pm 2.51 \\
(13.96-24.18)\end{array}$ & $\begin{array}{l}16.9 \pm 4.45 \\
(9.05-27.66)\end{array}$ & 0.827 & 0.738 \\
\hline G & $\begin{array}{l}53.43 \pm 2.02 \\
(49.39-57.44)\end{array}$ & $\begin{array}{l}58.09 \pm 2.25 \\
(53.54-62.54)\end{array}$ & $\begin{array}{l}54.93 \pm 4.18 \\
(46.36-63.28)\end{array}$ & 0.126 & 0.780 \\
\hline A & $\begin{array}{l}46.57 \pm 2.02 \\
(42.56-50.61)\end{array}$ & $\begin{array}{l}41.91 \pm 2.25 \\
(37.46-46.46)\end{array}$ & $\begin{array}{l}45.07 \pm 4.18 \\
(36.72-53.64)\end{array}$ & 0.126 & 0.780 \\
\hline \multicolumn{6}{|l|}{ CXCR2 } \\
\hline $\mathrm{T} / \mathrm{T}$ & $\begin{array}{l}34.1 \pm 2.71 \\
(28.79-39.72)\end{array}$ & $\begin{array}{l}30.47 \pm 3.02 \\
(24.63-36.82)\end{array}$ & $\begin{array}{l}32.86 \pm 5.61 \\
(22.09-45.12)\end{array}$ & 0.404 & 0.889 \\
\hline $\mathrm{T} / \mathrm{C}$ & $\begin{array}{l}46.56 \pm 2.86 \\
(40.85-52.33)\end{array}$ & $\begin{array}{l}51.5 \pm 3.27 \\
(44.89-58.08)\end{array}$ & $\begin{array}{l}60 \pm 5.86 \\
(47.59-71.53)\end{array}$ & 0.259 & $\begin{array}{l}\mathbf{0 . 0 4 7} \\
1.72(1.01-2.92)\end{array}$ \\
\hline $\mathrm{C} / \mathrm{C}$ & $\begin{array}{l}19.34 \pm 2.26 \\
(15.06-24.23)\end{array}$ & $\begin{array}{l}18.03 \pm 2.52 \\
(13.31-23.57)\end{array}$ & $\begin{array}{l}7.14 \pm 3.08 \\
(2.36-15.89)\end{array}$ & 0.73 & $\begin{array}{l}\mathbf{0 . 0 1 3} \\
0.32(0.12-0.83)\end{array}$ \\
\hline $\mathrm{T}$ & $\begin{array}{l}57.38 \pm 2 \\
(53.34-61.34)\end{array}$ & $\begin{array}{l}56.22 \pm 2.3 \\
(51.58-60.78)\end{array}$ & $\begin{array}{l}63.64 \pm 4.19 \\
(54.82-71.83)\end{array}$ & 0.710 & 0.206 \\
\hline $\mathrm{C}$ & $\begin{array}{l}42.62 \pm 2 \\
(38.66-46.66)\end{array}$ & $\begin{array}{l}43.78 \pm 2.3 \\
(39.22-48.42)\end{array}$ & $\begin{array}{l}36.36 \pm 4.19 \\
(28.17-45.18)\end{array}$ & 0.710 & 0.206 \\
\hline \multicolumn{6}{|l|}{ CCL18 } \\
\hline $\mathrm{T} / \mathrm{T}$ & $\begin{array}{l}18.61 \pm 2.35 \\
(14.18-23.74)\end{array}$ & $\begin{array}{l}33.8 \pm 3.22 \\
(27.52-40.53)\end{array}$ & $\begin{array}{l}24.24 \pm 5.27 \\
(14.54-36.36)\end{array}$ & $\begin{array}{l}\mathbf{0 . 0 0 0 2} \\
2.23(1.47-3.38)\end{array}$ & 0.305 \\
\hline $\mathrm{T} / \mathrm{C}$ & $\begin{array}{l}53.65 \pm 3.01 \\
(47.55-59.67)\end{array}$ & $\begin{array}{l}44.44 \pm 3.38 \\
(37.7-51.34)\end{array}$ & $\begin{array}{l}51.52 \pm 6.15 \\
(38.88-64.01)\end{array}$ & $\begin{array}{l}\mathbf{0 . 0 4 6} \\
0.67(0.47-0.96)\end{array}$ & 0.785 \\
\hline $\mathrm{C} / \mathrm{C}$ & $\begin{array}{l}27.74 \pm 2.7 \\
(22.52-33.44)\end{array}$ & $\begin{array}{l}21.76 \pm 2.81 \\
(16.45-27.86)\end{array}$ & $\begin{array}{l}24.24 \pm 5.27 \\
(14.54-36.36)\end{array}$ & 0.142 & 0.645 \\
\hline $\mathrm{T}$ & $\begin{array}{l}45.44 \pm 2.13 \\
(41.21-49.71)\end{array}$ & $\begin{array}{l}56.02 \pm 2.39 \\
(51.19-60.76)\end{array}$ & $\begin{array}{l}50 \pm 4.35 \\
(41.18-58.82)\end{array}$ & $\begin{array}{l}\mathbf{0 . 0 0 1} \\
1.53(1.19-1.97)\end{array}$ & 0.382 \\
\hline $\mathrm{C}$ & $\begin{array}{l}54.56 \pm 2.13 \\
(50.29-58.79)\end{array}$ & $\begin{array}{l}43.98 \pm 2.39 \\
(39.24-48.81)\end{array}$ & $\begin{array}{l}50 \pm 4.35 \\
(41.18-58.82)\end{array}$ & $\begin{array}{l}\mathbf{0 . 0 0 1} \\
0.65(0.5-0.84)\end{array}$ & 0.382 \\
\hline \multicolumn{6}{|l|}{ CCR2 } \\
\hline $\mathrm{V} / \mathrm{V}$ & $\begin{array}{l}74.84 \pm 2.48 \\
(69.58-79.6)\end{array}$ & $\begin{array}{l}66.52 \pm 3.13 \\
(59.97-72.63)\end{array}$ & $\begin{array}{l}75.38 \pm 5.34 \\
(63.13-85.23)\end{array}$ & $\begin{array}{l}\mathbf{0 . 0 4 2} \\
0.67(0.46-0.98)\end{array}$ & 1.000 \\
\hline $\mathrm{V} / \mathrm{I}$ & $\begin{array}{l}23.86 \pm 2.44 \\
(19.19-29.04)\end{array}$ & $\begin{array}{l}31.28 \pm 3.08 \\
(25.31-37.75)\end{array}$ & $\begin{array}{l}23.08 \pm 5.23 \\
(13.53-35.19)\end{array}$ & 0.061 & 1.000 \\
\hline $\mathrm{I} / \mathrm{I}$ & $\begin{array}{l}1.31 \pm 0.65 \\
(0.36-3.31)\end{array}$ & $\begin{array}{l}2.2 \pm 0.97 \\
(0.72-5.07)\end{array}$ & $\begin{array}{l}1.54 \pm 1.53 \\
(0.04-8.28)\end{array}$ & 0.506 & 1.000 \\
\hline V & $\begin{array}{l}86.76 \pm 1.37 \\
(83.82-89.35)\end{array}$ & $\begin{array}{l}82.16 \pm 1.8 \\
(78.32-85.57)\end{array}$ & $\begin{array}{l}86.92 \pm 2.96 \\
(79.89-92.19)\end{array}$ & $\begin{array}{l}\mathbf{0 . 0 4 7} \\
0.7(0.5-0.98)\end{array}$ & 1.000 \\
\hline I & $\begin{array}{l}13.24 \pm 1.37 \\
(10.65-16.18)\end{array}$ & $\begin{array}{l}17.84 \pm 1.8 \\
(14.43-21.68)\end{array}$ & $\begin{array}{l}13.08 \pm 2.96 \\
(7.81-20.11)\end{array}$ & $\begin{array}{l}\mathbf{0 . 0 4 7} \\
1.42(1.02-1.99)\end{array}$ & 1.000 \\
\hline
\end{tabular}

$\mathrm{p} \pm \mathrm{s}_{\mathrm{p}}=$ Genotype/allele frequency \pm standard error; $\mathrm{p}=$ level of significance $(\mathrm{p}<0.05$ are given in bold) 


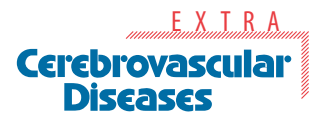

\begin{tabular}{l|l}
\hline Cerebrovasc Dis Extra 2015:5:124-131 \\
\hline DOI: 10.1159/000441529 & $\begin{array}{l}\text { (C) 2015 The Author(s). Published by S. Karger AG, Basel } \\
\text { www.karger.com/cee }\end{array}$
\end{tabular}

Timasheva et al.: The CXCR2 Gene Polymorphism Is Associated with Stroke in Patients with Essential Hypertension

Table 3. Allele and genotype combinations most significantly associated with stroke

\begin{tabular}{|c|c|c|c|c|c|c|c|c|c|c|c|}
\hline $\begin{array}{l}\text { CXCR2 } \\
\text { rs1126579 }\end{array}$ & $\begin{array}{l}\text { CCR5 } \\
\text { rs333 }\end{array}$ & $\begin{array}{l}\text { CCL2 } \\
\text { rs1024611 }\end{array}$ & $\begin{array}{l}I L 8 \\
\text { rs } 4073\end{array}$ & $\begin{array}{l}\text { CX3CR1 } \\
\text { rs3732378 }\end{array}$ & $\begin{array}{l}\text { CCL18 } \\
\text { rs8073066 }\end{array}$ & $\begin{array}{l}\text { Control, } \\
\%\end{array}$ & $\begin{array}{l}\text { Stroke, } \\
\%\end{array}$ & $\begin{array}{l}\text { Fisher's } \\
\text { p value }\end{array}$ & $P_{\text {perm }}$ & OR & $\mathrm{CI}_{\mathrm{OR}}$ \\
\hline $\mathrm{T}$ & $\mathrm{I} / \mathrm{I}$ & & & & & 63.92 & 82.09 & 0.0028 & 0.016 & 2.59 & $1.32-5.08$ \\
\hline $\mathrm{C} / \mathrm{C}$ & & A & & & & 6.15 & 19.61 & 0.005 & 0.026 & 0.27 & $0.09-0.77$ \\
\hline $\mathrm{T}$ & I & & & & & 92.54 & 79.22 & 0.006 & 0.032 & 3.25 & $1.25-8.50$ \\
\hline $\mathrm{C} / \mathrm{C}$ & & & $\mathrm{C}$ & & & 4.76 & 17.33 & 0.0067 & 0.032 & 0.24 & $0.07-0.80$ \\
\hline $\mathrm{C} / \mathrm{C}$ & & & & $\mathrm{T}$ & & 6.25 & 19.05 & 0.0075 & 0.035 & 0.28 & $0.10-0.82$ \\
\hline $\mathrm{T}$ & & $\mathrm{G}$ & & & A & 43.75 & 27.06 & 0.0082 & 0.035 & 2.1 & $1.19-3.69$ \\
\hline
\end{tabular}

$\mathrm{P}_{\text {perm }}=$ Standard permutation $\mathrm{p}$ value

between patients with stroke and the control group, while the frequencies of the CXCL1 rs4074, CCL18 rs8073066, and CCR2 rs1799864 genotypes were significantly different in the group of patients with noncomplicated $\mathrm{EH}$ compared to the control group.

We observed a statistically significant increase in CXCR2*T/C genotype frequency in the group of patients with stroke (60 vs. $46.56 \%$ in the control group, $\mathrm{p}=0.047$ ) and a reduction of the number of the $C X C R 2 * \mathrm{C}$ allele homozygotes in the same group $(7.14 \mathrm{vs} .19 .34 \%, \mathrm{p}=$ $0.013)$. The analysis of the association has shown that the carriers of the $C X C R 2^{*} \mathrm{~T} / \mathrm{C}$ genotype had a higher risk of stroke $(\mathrm{OR}=1.72,95 \% \mathrm{CI} 1.01-2.92)$. The $C X C R 2{ }^{*} \mathrm{C} / \mathrm{C}$ genotype was associated with a decreased risk of stroke (OR $=0.32,95 \%$ CI $0.12-0.83)$.

The group of patients with noncomplicated $\mathrm{EH}$ was characterized by overrepresentation of the $C X C L 1 * \mathrm{G} / \mathrm{G}$ genotype (34.85 vs. $26.47 \%$ in the control group, $\mathrm{p}=0.039$, $\mathrm{OR}=1.49,95 \%$ CI 1.03-2.15). CCL18*T/T genotype frequency was also significantly increased in patients with noncomplicated EH (33.8 vs. $18.61 \%, \mathrm{p}=0.0002$, OR $=2.23,95 \%$ CI $1.47-3.38$ ). The CCL18*T/C genotype and C allele were associated with a lower risk of $\mathrm{EH}(\mathrm{OR}=0.67,95 \% \mathrm{CI}$ $0.47-0.96, \mathrm{p}=0.046$, and $\mathrm{OR}=0.65,95 \%$ CI $0.5-0.84, \mathrm{p}=0.001$, respectively). Comparing the CCR2 rs1799864 polymorphism genotype and allele frequency distribution in patients with noncomplicated $\mathrm{EH}$ with the control group, we found a reduced number of $C C R 2 \mathrm{~V} / \mathrm{V}$ genotype carriers (66.52 vs. $77.84 \%$ in the control group, $\mathrm{p}=0.042$, OR $=0.67,95 \% \mathrm{CI} 0.46-0.98$ ). The CCR $2 *$ I allele was associated with an increased risk of EH (OR $=1.42,95 \%$ CI 1.02-1.99, p = $0.047)$.

Using the APSampler algorithm, we obtained 2,587 genotype/allele combinations of the studied polymorphic variants associated with stroke. Combinations that remained significantly associated with stroke after the permutation test had been applied are presented in table 3. A total of 6 genotype/allele combinations corresponded to the aforementioned criteria. CXCR2 rs1126579 was present in all combinations, CCR5 rs333 and CCL2 rs1024611 were featured in two combinations each, IL8 rs4073, CX3CR1 rs3732378, and CCL18 rs8073066 made an appearance once. Three patterns were associated with an increased risk of stroke, and three were found to be protective against it.

\section{Discussion}

In our study, we have shown that the risk of stroke in EH patients is associated with the CXCR2 rs1126579 polymorphism. CXCR2 is involved in the control of immune cell trafficking between bone marrow, blood, and peripheral tissues during inflammation. CXCR2-mediated signals promote the release of neutrophils into blood and into tissues, promote monocyte 
adhesion to the endothelium, and stimulate mast cell migration to peripheral tissues [1]. The rs1126579 polymorphism (T-to-C substitution at position 1235 in the $3^{\prime}$-UTR of the CXCR2 gene) is reportedly located in the microRNA-binding site and affects CXCR2 protein expression [3]. This polymorphism has been linked with different types of cancer, and the interaction between rs1126579-T and high serum levels of IL8, its endogenous ligand, has been demonstrated to play an important role in the protection from cancer [3].

There was no association observed between stroke and other polymorphisms when analyzed individually. However, the analysis of gene-gene interactions has revealed three combinations associated with stroke (table 2). It is worth noting that all combinations associated with stroke in hypertensive patients included the CXCR2 rs1126579 polymorphism, and the $C X C R 2^{*}$ T allele was part of all three combinations predisposing to stroke. Protective combinations included, in addition to the $C X C R 2^{*} \mathrm{C} / \mathrm{C}$ genotype, $C C L 2^{*} \mathrm{~A}, I L 8^{*} \mathrm{C}$, or the $C X 3 C R 1^{*} \mathrm{~T}$ allele.

While the importance of the interaction between CXCR2 and its ligand IL8 has already been established, the CXCR2 interplay with other chemokines is less clear. The CCR5 32 (rs333) polymorphism consists of a 32-bp deletion and results in frameshift mutation that produces defective protein-lacking regions responsible for signal transduction [4]. The implication of this polymorphism in the susceptibility to HIV infection has been extensively investigated [4]. The CCR $5^{*} \mathrm{D}$ allele was shown to be protective against cerebrovascular events in patients with rheumatoid arthritis [5]. An association was detected between CCR5 32 deletion and increased plasma high-density lipoprotein cholesterol and decreased plasma triglyceride levels [6]. Balistreri et al. [7] reported an association between the CCR5*I/I genotype and myocardial infarction in the Sicilian population. This genotype was also reported to negatively affect the chances of longevity. However, no association with myocardial infarction was detected in the Russian population [8]. In our study, we discovered that the CCR $5^{*}$ I/I genotype and CCR ${ }^{*}$ I allele are included in the patterns associated with stroke. The lack of association with $C C R 5^{*} \mathrm{D}$ may be due to the small sample size.

The CCL2 rs $1024611^{*} \mathrm{G}$ allele was previously found to be associated with increased CCL2 expression, higher CCL2 serum levels, and enhanced leukocyte recruitment to the tissues [9, 10]. There is abundant evidence of the implication of this polymorphism in different disease phenotypes, but the results are often inconsistent, which may reflect the linkage between rs1024611 and another CCL2 polymorphism, rs13900 [11]. No association has been found between the CCL2 plasma level and major adverse cardiovascular and cerebrovascular events [12]. Other genes may also have an impact on rs1024611 effects, as shown in our study.

The rs3732378 polymorphism in the exon 2 of the CX3CR1 gene results in threonine-tomethionine substitution at position 280 and results in a reduced affinity to fractalkine [13, 14]. An association was reported between the $C X 3 C R 1^{*} \mathrm{M}$ allele and a decreased risk of carotid atherosclerosis [15]. However, the $C X 3 C R 1^{*} \mathrm{M} / \mathrm{M}$ genotype has been shown to increase the risk of ischemic cerebrovascular disease [16]. This observation is in line with our finding that the $C X 3 C R 1^{*} \mathrm{~T}$ allele is a part of a combination protective against stroke.

A triallelic pattern associated with an increased stroke risk included the rs8073066 polymorphism located near the CCL18 gene. This SNP is virtually unexplored, and there is no data on its functionality or implication for disease development. All the more interesting is the fact that in our study, this polymorphism was found to be associated with the risk of EH without cardiovascular or cerebrovascular complications. It happens to be the only cross-link between the observed patterns of associations for stroke and noncomplicated $\mathrm{EH}$, since the risk of the latter was found to be associated with the only two of the studied gene markers that were absent in the genotype/allele combinations associated with stroke: CCR2 rs1799864 and CXCL1 rs4074. 
Timasheva et al.: The CXCR2 Gene Polymorphism Is Associated with Stroke in Patients with Essential Hypertension

The results of our study show that the CXCR2 rs1126579 polymorphism is significantly associated with ischemic stroke, both individually and in combination with the genotype and/or alleles of other chemokine genes. Further investigation is needed in order to elucidate the exact role of the CXCR2 chemokine receptor in the pathogenesis of stroke, but selective antagonism of the interaction between this receptor and its many ligands may be a promising strategy for stroke therapy. CXCR2 antagonists have already been studied in the treatment of respiratory diseases such as chronic obstructive pulmonary disease and asthma and were shown to reduce neutrophil recruitment into the lung and diminish underlying inflammation [17-20]. The noncompetitive allosteric antagonist of the CXCR1 and CXCR2 chemokine receptors was found to be protective against brain damage in the murine models of middle cerebral artery occlusion and reperfusion [21,22]. Treatment with the CXCR2 ligand-binding protein Evasin-3 was associated with a reduction in ischemic brain neutrophil infiltration at early stages of ischemic brain injury in mice; however, it did not show further beneficial effects on stroke outcome, which may reflect the complexity of the nonselective ligandreceptor interaction [23].

\section{Acknowledgements}

We thank all participants of this study for completing questionnaires and providing blood samples. We also thank Dr. Emma M. Kolchina and Irina M. Karamova for assistance in collecting blood samples. The study was supported by the Russian Foundation for Basic Research, grant No. 13-04-01561-a.

\section{References}

$>1$ Griffith JW, Sokol CL, Luster AD: Chemokines and chemokine receptors: positioning cells for host defense and immunity. Annu Rev Immun 2014;32:659-702.

-2 Favorov AV, Andreewski TV, Sudomoina MA, Favorova 00, Parmigiani G, Ochs MF: A Markov chain Monte Carlo technique for identification of combinations of allelic variants underlying complex diseases in humans. Genetics 2005;171:2113-2121.

-3 Ryan BM., Robles AI, McClary AC, et al: Identification of a functional SNP in the $3^{\prime}$ UTR of CXCR2 that is associated with reduced risk of lung cancer. Cancer Res 2015;75:566-575.

4 Barmania F, Pepper M: CC chemokine receptor type five (CCR5): an emerging target for the control of HIV infection. Appl Transl Genom 2013;2:3-16.

-5 Rodríguez-Rodríguez L, González-Juanatey C, García-Bermúdez M, Vázquez-Rodríguez TR, Miranda-Filloy JA, Fernández-Gutiérrez B, Llorca J, Martin J, González-Gay MA: CCR5 32 variant and cardiovascular disease in patients with rheumatoid arthritis: a cohort study. Arthritis Res Ther 2011;13:R133.

66 Breunis WB, Biezeveld MH, Geissler J, Kuipers IM, Lam J, Ottenkamp J, Hutchinson A, Welch R, Chanock SJ, Kuijpers TW: Polymorphisms in chemokine receptor genes and susceptibility to Kawasaki disease. Clin Exp Immunol 2007;150:83-90.

7 Balistreri CR, Candore G, Caruso M, Incalcaterra E, Franceschi C, Caruso C: Role of polymorphisms of CC-chemokine receptor-5 gene in acute myocardial infarction and biological implications for longevity. Haematologica 2008;93:637-638.

-8 Sukhinina TS, Shakhnovich RM, Barsova RM, Matveeva NA, Titov BN, Sudomoina MA, Favorova O0, Ruda MI: Value of allele gene polymorphism of the inflammation system for prognosis of patients with myocardial infarction (in Russian). Kardiologiia 2011;52:15-21.

-9 Rovin BH, Lu L, Saxena R: A novel polymorphism in the MCP-1 gene regulatory region that influences MCP-1 expression. Biochem Biophys Res Commun 1999;259:344-348.

10 Gonzalez E, Rovin BH, Sen L, Cooke G, Dhanda R, Mummidi S, Kulkarni H, Bamshad MJ, Telles V, Anderson SA, Walter EA, Stephan KT, Deucher M, Mangano A, Bologna R, Ahuja SS, Dolan MJ, Ahuja SK: HIV-1 infection and AIDS dementia are influenced by a mutant MCP-1 allele linked to increased monocyte infiltration of tissues and MCP-1 levels. Proc Natl Acad Sci USA 2002;99:13795-13800.

11 Pham MHT, Bonello GB, Castiblanco J, Le T, Sigala J, He W, Mummidi S: The rs1024611 regulatory region polymorphism is associated with CCL2 allelic expression imbalance. PloS One 2012;7:e49498. 
12 Guo Y, Apostalakis S, Blann AD, Lip GY: Plasma CX3CL1 levels and long term outcomes of patients with atrial fibrillation: the West Birmingham Atrial Fibrillation Project. Cerebrovasc Dis 2014;38:204-211.

13 Faure S, Meyer L, Costagliola D, Vaneensberghe C, Genin E, Autran B, Delfraissy JF, McDermott DH, Murphy PM, Debre P, Theodorou I, Combadière C: Rapid progression to AIDS in HIV+ individuals with a structural variant of the chemokine receptor CX3CR1. Science 2000;287:2274-2277.

14 McDermott DH, Fong AM, Yang Q, Sechler JM, Cupples LA, Merrel MN, Wilson PW, D’Agostino RB, O’Donnel CJ, Patel DD, Murphy PM: Chemokine receptor mutant CX3CR1-M280 has impaired adhesive function and correlates with protection from cardiovascular disease in humans. J Clin Invest 2003;111:1241-1250.

15 Zhao R, Wang Y, Shen R, Sun Y: Relationship between CX3CR1 genetic polymorphism and carotid atherosclerosis. Artif Cells Blood Substit Immobil 2010;38:19-23.

16 Wu J, Yin RX, Lin QZ, Guo T, Shi GY, Sun JQ, Shen SW, Li Q: Two polymorphisms in the Fractalkine receptor CX3CR1 gene influence the development of atherosclerosis: a meta-analysis. Dis Markers 2014;2014:913678.

17 Chapman RW, Phillips JE, Hipkin RW, Curran AK, Lundell D, Fine JS: CXCR2 antagonists for the treatment of pulmonary disease. Pharmacol Ther 2009;121:55-68.

-18 Todd CM, Murphy DM, Watson RM, Howie K, Strinich TX, Peng K, Nykamp A, Killian KJ, Khanskaya I, Sadeh J, Boulet LP, O’Byrne P, Gavreau GM: Treatment with the CXCR2 antagonist SCH527123 reduced neutrophil levels in blood and airways but not bone marrow in mild asthmatic subjects. Am J Respir Crit Care Med 2010; 181:A4237.

19 Nair P, Gaga M, Zervas E, Alagha K, Hargreave FE, O’Byrne PM, Stryszak P, Gann L, Sadeh J, Chanez P: Safety and efficacy of a CXCR2 antagonist in patients with severe asthma and sputum neutrophils: a randomized, placebo-controlled clinical trial. Clin Exp Allergy 2012;42:1097-1103.

20 Magnussen H, Holz O, Watz H, Sauer M, Khanskaya I, Gann L, Stryszak P, Sadeh J: Safety and efficacy of SCH527123, a novel CXCR2 antagonist, in patients with COPD. Eur Respir J 2010;36(suppl 54):38S.

-21 Sousa LFC, Coelho FM, Rodrigues DH, Campos AC, Barcelos LDS, Teixeira MM, Teixeira AL: Blockade of CXCR1/2 chemokine receptors protects against brain damage in ischemic stroke in mice. Clinics 2013;68: 391-394.

-22 Connell BJ, Gordon JR, Saleh TM: ELR-CXC chemokine antagonism is neuroprotective in a rat model of ischemic stroke. Neurosci Lett 2015;606:117-122.

-23 Copin JC, da Silva RF, Fraga-Silva RA, Capettini L, Quintao S, Lenglet S, Pelli G, Galan K, Burger F, Braunersreuther V, Schaller K, Deruaz M, Proudfoot AE, Dallegri F, Stergiopulos N, Santos RAS, Gasche Y, Mach F, Montecucco F: Treatment with Evasin-3 reduces atherosclerotic vulnerability for ischemic stroke, but not brain injury in mice. J Cereb Blood Flow Metab 2013;33:490-498. 